\title{
Sustainability Strategy for Profit Sharing Systems for Beef Cattle Farmers with Institutions in Terms of Economic Aspects
}

\section{${ }^{1}$ A.R. Siregar, ${ }^{1}$ S.N. Sirajuddin, ${ }^{1}$ V.S. Lestari and ${ }^{2}$ N. Fitrianti}

${ }^{1}$ Department of Socio-Economics, Faculty of Animal Husbandry, Hasanuddin University, Makassar, South Sulawesi, Indonesia ${ }^{2}$ Department of Study of Development, Faculty of Economics, Hasanuddin University, Makassar, South Sulawesi, Indonesia

Correspondence Author: A.R. Siregar, Department of Socio-Economics, Faculty of Animal Husbandry, Hasanuddin University, Makassar, South Sulawesi, Indonesia

Telp: $+62411-586200$

Fax: +62411-585188

E-mail: sitti.nurani@unhas.ac.i

Received date: 23 June 2018, Accepted date: 30 August 2018, Online, Online date: 22 September 2018

Copyright: (C) 2018 A.R. Siregar et al., This is an open-access article distributed under the terms of the Creative Commons Attribution License, which permits unrestricted use, distribution, and reproduction in any medium, provided the original author and source are credited.

\begin{abstract}
The presence of MBC with the results of the system activities carried out with farmers in Barru district is expected to be a solution for farmers in increasing their income as well as efforts to improve the quality and productivity of local cattle. This study aimed to determine the strategy of continuity of the cattle breeding system with institutions (Maiwa breeding Center) in terms of socio-economic aspects. The study was conducted from June to July 2018 in the District of Tanete Riaja, Barru Regency, South Sulawesi Province, Indonesia. This type of research is quantitative descriptive. The population in this study is a beef cattle farmer who cooperates with the maintenance of breeding Maiwa Breeding Center. The sample is a beef cattle farmer who perform profit sharing system in Lempang Village, Tanete Riaja Subdistrict as many as 40 farmers. The type of data used in this study is the type of qualitative data and quantitative data. Data source used in this research is primary data and secondary data. The data collection method used is observation and interview. The analysis used descriptive statistic is frequency distribution. The results of the study show that the profit sharing system can continue if viewed from an economic aspect so the system contract can pay attention to the costs incurred by farmers during cattle maintenance.
\end{abstract}

Key words: sharing system, strategy, sustainability

\section{INTRODUCTION}

Beef cattle have the greatest contribution as a producer of beef, and during this time have not been able to meet domestic demand which tends to increase every year. Increased demand for beef cattle development opportunities locally with scale agribusiness through a partnership [1],[2]. Business development of cattle with a partnership is one alternative to improve the profitability of farmers and could overcome some of the problems in the beef cattle business namely small scale cattle raising and limited capital [3],[4,[5]. Based on problems existed in the beef cattle business, the partnership program is indispensable. [6] stated that the partnership is a system of alliances the various agribusiness activities ranging from preproduction, production to marketing.

During this time, the partnership system with profit sharing carried out on livestock businesses was mostly done formally both with the private sector and with the government. While partnerships between educational institutions are carried out between beef cattle farmers and Hasanuddin University at the Maiwa Breeding Center located in Maiwa District, Enrekang Regency, South Sulawesi Province, Indonesia. The research center named Maiwa Breeding Center (MBC) which was officially built in Enrekang Regency, South Sulawesi. Maiwa Breeding Center (MBC), which is located in 250 ha, has been designated by LIPI as the Techno Park area which is one of the research centers for nurseries, development and science. In addition, the Maiwa Breeding Center located in the National Strategic Area (KSN) Kapet Pare-pare which is a center for livestock development, has good potential to grow into a local cattle breeding center, to meet the needs of cattle, both at the district, provincial and for Sulawesi [7]

In addition to conducting an empowerment program for the communities around MBC, especially in Bangkala Village, Maiwa Subdistrict, Enrekang District is also in the new district by partnering with cattle farmers through a system of compensation with contracts implemented between the two parties. With the implementation of the system, MBC is expected to be able to become a business unit of the surrounding livestock farmer groups and to support the availability of seed cows in order to achieve meat self-sufficiency in South Sulawesi Province and in Indonesia in general [8]

The momentum of business cooperation with the partnership system is the main choice at this time. Business cooperation with the partnership system is realized in contracts that bind the parties to the agreement. The contract contains a number of clauses that must be obeyed by the parties, but still must pay attention to a number of ethics and regulations that apply. The contract must consider the principle of equality and balance so that it must benefit the parties. The contracts carried out also do not violate the principles of fair business competition and do not lead to monopolistic practices [9].

The profit system is the system in which a joint agreement or bond takes place in carrying out business activities. In this effort promised the distribution of the results of the profits to be obtained between the two parties or more, this term is usually called teseng / Tesang in South Sulawesi Province [10]. 
Citation: A.R. Siregar, 2018. Sustainability Strategy for Profit Sharing Systems for Beef Cattle Farmers with Institutions in Terms of Economic Aspects Advances in Environmental Biology., 12(9): 8-10.

The continuity of collaboration between MBC and breeders depends on how farmers know, pay attention to and behave towards the cooperation system. If the farmer thinks positively about the system of collaboration with MBC, it will influence the farmer's response that the program is good to do and still encourage farmers to continue the program. Collaborating with MBC breeders can get cattle and income from the sharing system. But if the farmer is not well aware of the system of collaboration carried out with MBC, it will risk that the farmer does not respond well to the program and chooses not to continue the cattle maintenance cooperation contract with MBC. Field conditions state that there are farmers who do not continue the contract before the deadline for the contract expires, so that the need for continuation of cooperation between beef cattle farmers and MBC. For sustainability of the intermediate system between farmers, it can be reviewed from several aspects including economic aspects. Therefore, with a system of results made between the MBC and beef cattle farmers, it is necessary to know the strategies that need to be done for the sustainability of the production system in terms of economic aspects that is from income and business scale

\section{MATERIAL AND METHODS}

The study was conducted from May to June 2018 in Tanete Riaja Sub-district, Barru District, South Sulawesi Province, Indonesia. This type of research is quantitative descriptive. The population in this research is beef cattle farmers who cooperate with the instution with Maiwa Breeding Center in Barru Regency, South Sulawesi Province, Indonesia. Sampling is purposively ie farmers use sharing system with MBC in Lempang Village, Tanaje Riaja district, Barru Regency which as many as 40 farmers. Data type used in this study is the type of qualitative data and quantitative data. Data source used in this research is primary data namely data taken based on interviews and using a temporary questionnaire and secondary data namely data taken from relevant agencies. The data collection method used is observation and Interview. The analysis used descriptive statistic is frequency distribution table.

\section{RESULT AND DISCUSSION}

Characteristics of Respondents:

Characteristics of farmers greatly affect in the management of livestock business such as age, education level, family size, business scale and duration of raising [11],[12]. The characteristics of breeders who follow the sharing system with MBC that can be seen in Table 1.

Table. 1. Characteristics of beef cattle ranchers who follow profit sharing system with MBC in Tanete Riaja Sub-district, Barru District

Table. 1. Characteristics of beef cattle ranchers who follow profit sharing system with MBC in Tanete Riaja Sub-district, Barru District
\begin{tabular}{|l|l|l|l|}
\hline Characteristics & Description & Number & Percentage \\
\hline \multirow{4}{*}{ Age } & $0-14$ & 0 & 0 \\
\cline { 2 - 4 } & $15-64$ & 39 & 97.5 \\
\cline { 2 - 4 } & 65 & 1 & 2.5 \\
\hline \multirow{4}{*}{ Level of Education } & Bachelor & 1 & 2,5 \\
\cline { 2 - 4 } & Senior High School & 7 & 17,5 \\
\cline { 2 - 4 } & Junior High School & 13 & 32,5 \\
\cline { 2 - 4 } & Primary School & 19 & 47,5 \\
\hline \multirow{2}{*}{ Gender } & Male & 35 & 55 \\
\cline { 2 - 4 } & Woman & 5 & 5 \\
\hline \multirow{3}{*}{ Number of Livestock Ownership } & $1-5$ & 20 & 50 \\
\cline { 2 - 4 } & $6-10$ & 19 & 47,5 \\
\cline { 2 - 4 } & $>10$ & 1 & 2,5 \\
\hline
\end{tabular}

Source: Primary of data (2018)

Table 1 shows that $97.5 \%$ of respondents are 15-64 years old, which means that the average farmer in Lempang Village, Tanete Riaja Sub-district, Barru District, is still in the productive age group to do the work or run the business. The ability to work a person is strongly influenced by the age factor. This is in accordance with the opinion [13] which states that the level of work productivity of a person will experience an increase in accordance with age, then will decline again before old age

Table 1 show that the number of respondents by sex, males is $87.5 \%$, and women are $12.5 \%$. Considering that this effort requires a greater effort in maintaining it. However, it is possible if in the men to cooperate with each other. This is in accordance with [14] opinion that proper handling and proper positioning of job positions will also increase effectiveness and productivity as the trigger of success of a business.

Table 1, shows that most farmers have formal education at the elementary and junior high level of $80 \%$. While the level of education Bachelor as much as 1 person with the lowest percentage of $2.5 \%$. This suggests that higher education allows farmers to further develop themselves and manage their thinking patterns to absorb new technologies, whereas low education will be difficult to adopt new technologies that will be applied to them to facilitate the completion of the work undertaken and also low education would have an impact on their less knowledge in accepting their new knowledge of adversity. Education is also very important to support the progress of the business. This is in accordance with the opinion of [15] which states that, the level of education affects the ability of farmers in the application of technology; in addition the level of education can be used as a benchmark to the ability to think someone in the face of problems in the family can be addressed. If education is low then the power of thought narrow then the ability to propagate a new innovation will be limited, so the insight to progress lowers than the highly educated breeders. Higher, more flexible breeders in responding to a problem, they will always try to improve their level of living better.

According to [16] that the scale of ownership of beef cattle farmers-farmers who are status as people's farms, are grouped into 3 parts, namely 1-5 tail, 6-10 tail, and $>10$ tail. Table 1 shows that the scale of ownership of beef cattle in Lempang Village, Tanete Riaja Sub-district, Barru District, averages around 1-5 (small scale) with $50 \%$ percentage and who own livestock with livestock ownership scale> 10 (Scale Large) is still slightly with $2.5 \%$ percentage. It can be concluded that in Lempang Village, TaneteRiaja Sub-district, Barru Regency is generally a beef cattle farming business for the people, this is reinforced because the average of livestock ownership is in small scale category with the number of cattle ranging from 1-5 cows. [17] states that the low scale of business is due to the farmers generally still raise cattle as a sideline business, where the main objective is saving, so that maintenance management is still done conventionally.

Sustainability Strategy the sharing system is viewed from the economic aspect:

Economic aspects in this study are indicators of farmers' business scale and income earned. The income obtained in this study was measured using three indicators, namely to prosper the livestock life, increase farmer income and meet needs (clothing, shelter and food). The farmer stated that partnering with the Maiwa Breeding Center could increase the income earned under the agreed cooperation contract. The respondent's answers when viewed from the economic aspect can be seen in Table 2

Table 2. The respondent's answers when viewed from the economic aspect in Tanete Riaja District

\begin{tabular}{|l|l|l|l|l|}
\hline No & Economy Aspects & Respondents answers (\%) & Doubtful & Disagree \\
\cline { 3 - 5 } & & Agree & 7,5 & 0 \\
\hline 1 & Scale enterprises & 92,5 & 25 & 25 \\
\hline 2 & Income & 50 & 25 & \\
\hline
\end{tabular}

Table 2 shows that $50 \%$ of beef cattle breeders who do a system of profit sharing with institutions (MBC) give a positive assessment of the results of the system implemented, this is in opinion accordance with [18] states that beef cattle breeding business with this profit sharing pattern, for most farmers, it has become the main source of income in addition to agricultural business activities and other business activities. This operating income is used to finance the 
Citation: A.R. Siregar, 2018. Sustainability Strategy for Profit Sharing Systems for Beef Cattle Farmers with Institutions in Terms of Economic Aspects

Advances in Environmental Biology., 12(9): 8-10.

household needs of farmers and the proceeds from the sale are used to finance rice cultivation, and are even saved / invested in the form of land purchases for agriculture.

Farmers feel more fortunate with the profit sharing pattern in the cattle breeding cooperation contract with the Maiwa Breeding Center. The form of profit sharing pattern for the Maiwa Breeding Center is 55\% for the second party, $40 \%$ for the first party and $5 \%$ for group development which is handled directly by the group leader. For the results in this collaboration system, farmers can choose whether to divide livestock or cash in according to the price of cows that are kept. In addition, farmers are only bound by a period of 1 year 6 months. Based on this, the breeders feel that the profit sharing pattern is better with this period. Compared to teseng where the farmer only gets $50 \%$ or by dividing the calf, but the farmer is bound with a period that cannot be determined.[9] states that the cattle distribution system is carried out if the cow gives birth to a calf in the first year, it is given to the owner, while in the second year, it is given to the farmer or vice versa according to the verbal agreement until the fifth year. From the results of the study by [19] it was found that the portion for noise was $2 / 3$ of body weight gain.

Breeders agree that partnering with $\mathrm{MBC}$ is able to increase the number of livestock owned by the percentage of $92.5 \%$. These breeders are given one to three cows to be kept, so that they can be bred to increase the population. Some farmers have just started to re-breed after partnering with MBC, because the cattle they had previously had sold out for breeders' needs. This is consistent with [20] opinion that community empowerment through education and training and providing supporting facilities according to the needs of the community will greatly influence the increased effort and quality of life of the community. As with the distribution of a number of cattle to farmers who are also given training and counseling so that later the farmers can increase their livestock population and of course the livestock population in the area will increase. This is in accordance with the opinion of [21] which states that the behavior of farmers in making decisions to invest in expanding their business is learning from previous investments and taking into account the values obtained by observing over time. If investment from time to time can provide added value or benefit, then the farmer will decide to invest so that in turn it can increase production and increase farmer income

Based on the business scale and income level of farmers, [22] classified livestock business into four groups, namely: 1) livestock as a sideline business, namely farmers cultivate agricultural commodities, especially food crops, while livestock is only a side business to meet family needs (subsistence) with the level of business income from livestock $<30 \%, 2$ ) animal husbandry as a business branch, that is the farmer strives for mixed farming with livestock and the level of income from livestock business reaches $30-70 \%, 3$ ) livestock as the main business, that is the livestock breeders as the main business with income levels ranging from $70-100 \%$, and 4) animal husbandry as an industry by cultivating livestock specifically (specialized farming) and the level of income from livestock businesses reaches $100 \%$.

The business scale in this case is closely related to the income earned by farmers as explained in the previous sub variable. The size of the business scale owned by farmers affects the income that will be obtained by the farmer. This relates to the characteristics of the business run by farmers, namely whether it includes the main business and side business. In this regard, the size or amount of livestock ownership owned by farmers but is very helpful in increasing income and meeting needs. This is in line with the opinion of [22] which states that the size of the business of cattle ownership greatly affects the level of income, so the higher the scale of business of ownership, the greater the level of income of farmers. Even though the response is positive, the strategy that needs to be done is by making a contract by calculating the costs incurred by the farmer during cattle maintenance so that the profits obtained by the breeders can also be greater than the resulting system.

\section{CONCLUSION}

A profit-sharing system between breeders and institutions can increase the scale of business and income but the Institution's managers should also pay attention to contracts that cover the costs incurred by farmers for maintenance to further increase the income of farmers who do the work.

\section{REFERENCE}

[1] Suryana, 2009. Business Development Oriented Agribusiness Beef Cattle with Partnership.Pattern of Agricultural Researchh Journal, 28(1).

[2] Guolingshi, Zhiwang Qian, Dangin Zhan,2007. Analysis of Supply Chain Principal-Agent incentive contract. International Journal of Management Science and Engineering Management, 2(2):155-160.

[3] Sirajuddin, S.N., I.M. Saleh, I. Rasyid, 2013. Role Teseng (Traditional Sharing System) in Beef Cattle Improvement population in Bone regency. Proceedings. National Seminar on Chemistry. The Role of Science and Technology in Improving Food Security and the National Energy

[4] Kariyasa, K. 2005. Sistemintegrasitanaman-ternakdalamperspektifreorientasikebijakansubsidipupukdanpeningkatanpendapatanpetani. Jurnal Analisis Kebijakan Pertanian, 3(1): 68-80.

[5] Mersyah, R., 2005. DesainsistembudidayasapipotongberkelanjutanuntukmendukungpelaksanaanotonomidaerahdiKabupatenBengkulu Selatan. Disertasi, Sekolah Pascasarjana, Institut Pertanian Bogor.

[6] Isbandi, 2004. Development of live stock farmers' groups in an effort to beef cattle J. Indon.Trop.Anim.Agric.29 (2):106-114.

[7] Saptana and Ashari, 2007. Sustainable development agriculture with partnership business. Journal of Research and Development Agriculture, 26(4):126-130.

[8] Risma, 2016. Kemenrisetdikti Kembangkan Industri Peternakan Berbasis Masyarakat. (www.mirajnews.com/id/kemenrisetdikti-kembangkan-industripeternakan-berbasis-masyarakat/108440. Mi'rajNews Agency. Diaksespadatanggall6 November 2017).

[9] Sirajuddin, S.N., A.R. Siregar, S. Nurlaelah, V.S. Lestari, V. Tenrisanna, 2017. The limitations and benefits of partnership sharing system of Corporated Cattle Market (CCM). American-Eurasian Journal of Sustainable Agriculture, 11(1): 11-15.

[10] SittiNurani Sirajuddin, Ahmad Ramadhan Siregar, Palmarudi Mappigau, 2017. Adoption Rate of Beef Breeders Technology Following Partnership System in Barru Regency.American-Eurasian Journal of Sustainable Agriculture, 11(6): 31-34.

[11] Sirajuddin, S.N., S. Nurlaelah, A. Amrawaty, T. Amrullah, S. Rohani and I.M. Saleh, 2017. Relationship Between Farmers Characteristic and Income from Beef Cattle with TheTraditional Profit-Sharing. American-eurasian journal of sustainable Agriculture, 11(5): 29-34.

[12] SittiNurani Sirajuddin, IkrarMoh. Saleh, Jamilah Mustabi and Syamsinar Syukur, 2018. Perceptive Farmers Viewed from Knowledge and Skills in Utilizing Beef cattleFeces into Organic Solid Fertilizer. Advances in Environmental Biology, 12(5):17-20.DOI : 10.22587/aeb.2018.12.5.5

[13] Swastha, B., I. Dan Sukartjo, 1997. PengantarBisnis Modern (Pengantar Ekonomi Perusahaan Modern). LibertyOffest Yogyakarta, Yogyakarta.

[14] Wahyono, 2013. PerbedaanPria dan Wanita dalam Pekerjaan-.http//www-.puncakbukit.blog.com./perbedaan-pria-dan-wanita-dalam-pekerjaan.html. Diakses pada (tanggal29 Maret 2018).

[15] Lestraningsih, M., E. Dan Basuki, 2008. Peran Serta Wanita Peternak SapiPerah Dalam Meningkatkan Taraf Hidup Keluarga. Jurnal Ekuitas. Sekolah Tinggi Ilmu Ekonomi Indonesia (STIESIA) Surabaya.

[16] Bessant, W., 2005. Analisis Usaha Peternakan Sapi Potong Dalam Kaitannyadengan Kesejahteraan Peternak di Kabupaten dan Kota Bogor. Prosiding Skripsi. Program PersetujuanManajemen dan Bisnis. IPB. Bogor.

[17] Firmansyah, C., S. Kuswaryan, S. Dan Rahayu, 2006. Manfaat Finansial pada Pola Kemitraan Usaha Pembibitan Sapi Potong. Jurnal Ilmu Ternak, 6(1):7580. Fakultas Peternakan. Universitas Padjadjaran.

[18] Lole, U.R., 1995. Kajian Ekonomi SistemBagi Hasil pada Pola Gaduhan Penggemukan Sapi Potong di Kawasan Timor Barat. Tesis. Fakultas Pascasrjana. Institut Pertanian Bogor. Bogor.

[19] Eko, S., 2002. Pemberdayaan Masyarakat Desa. Materi Diklat Pemberdayaan Masyarakat Desa. Badan Diklat Provinsi Kaltim. Samarinda.

[20] Maart-Noelck, S.C., O. Musshoff, 2013. Investing today or tomorrow? An experimental approach to farmers' decision behaviour. JAE, 64: 295-318.

[21] Anggraini, W., 2003. Analisis Usaha Peternakan Sapi Potong Rakyat Berdasarkan Biaya Produksidan Tingkat Pendapatan PeternakanMenurut Skala Usaha (Kasus di KecamatanWere Kabupaten Bima Nusa Tenggara Barat).Skripsi. Fakultas Peternakan Institut PertanianBogor.

[22] Paturochman, M., 2005. Hubunganantaratingkatpendapatankeluargapeternakdengantingkatkonsumsi (kasus di koperasipeternakan Bandung Selatan (KBPS) Pangalengan). Sosiohumaniora,7(3):Nopember 2005. www.resources.unpad.ac.id. Diakses, 25. 